УДК 821.163.41.09:398 Караџић, Вук Стефановић https://doi.org/10.18485/msc50_vuk_trsic.2021.ch17

Владимир Бован

\title{
СРПСКЕ НАРОДНЕ ПЕСМЕ СА КОСОВА У ЗБИРЦИ ВУКА СТЕФАНОВИКА КАРАЏИЋА
}

Вук Стефановић Караџић је први записивач српских народних песама са Косова. Записи песама потичу из 1821, када је Вук Караџић од Анђелка Вуковића из села Орахова код рудника Трепче записао пет јуначких народних песама и једну приповедну, бајку у стиху. Анђелко Вуковић, храбар човек и ратник, преокупиран трагичном судбином и епском повешћу свога народа, није казивао Вуку и лирске песме.

О Анђелку Вуковићу, једином Вуковом певачу са Косова, остало је врло мало писаних сведочанстава. О њему је Вук Караџић писао у белешци уз песму о змији младожењи у предговору књиге Народне српске nјесме (Лајпциг, 1823) и у „рачуну од јуначких песама” у књизи Народне српске пјесме (Беч, 1833). Вук наводи податке о Анђелку Вуковићу, који је песму о змији младожењи казивао у стиховима, а делом је и препричавао као приповетку: „Ову сам пјесму ја слушао у Крагујевцу од два човека: од једног Косовца и од једног Ерцеговца од Мостара. Од Косовца сам је овако преписао, но будући да је он био само пјевач од средње руке, зато је на ђекојим мјестима готово приповиједао (овако као и ја)". У рачуну је Вук навео да је Анђелко Вуковић „...родом из Косова из села Ораова у наији Вучитрнској, па убивши некаква Турчина, Синана (о чем је песма 45. у овој књизи), добежи амо међу Србе, и постане момак код њиове Свјетлости"2. Говорећи о Вуковићевој песми Анђелко Вуковић и Синан Кесеиија објаснио је њен настанак и указао на њену грађу: „Ову је последњу песму Анђелко спевао 1821. године путујући са мном два дана из Крагујевца у Београд, па онде заокупи једнога трговца, те му је ноћу препише, и сутри дан је мени преда. О историји истине њене толико ми је Анђелко при-

1 Вук Стеф. Караџић, Народне српске пјесме, књ. I, Лајпциг, 1824, предговор стр. XLVII.

2 Исто, стр. XXII. 
поведао, још пре, него је песму спевао, да је Синан, који му је још од пре претио, сретавши се с њим, ударио нањ, да га убије, но он убио њега, и по том побегао амо међу Србе”. У „рачуну” је Вук описао овог песника и ратника: „Анђелко је онда, када је ову песму спевао, био момак око 35 година, раста је средњега, леп, црномањаст, добар и побожан човек, али велики јунак (на Чачку га је 1815. године, баш када је дошао из Косова, ударило пушчано тане усред прсију, па изишло на леђа)"4.

Вуковог певача са Косова поменуо је и Атанасије Урошевић у својој књизи Косово 5 . Говорећи о исељеницима из предела Трепче на почетку XIX века наводи: „Међу исељенике из предела Трепче спада и онај Анђелко Вуковић из сада већ арбанашког села Орахова" ${ }^{\circ}$ Из Урошевићеве студије може се закључити да су арбанашки досељеници допрли већ почетком XIX века у пределе Косовске Митровице и Трепче и да су 1815. године населили село Кутловац, суседно српском селу Орахову, које се налазило на северној страни трепчанске долине. Да су ти досељеници из скадарске Малесије били муслиманске вере потврђују и њихова имена, па и име Анђелковог противника Синана, који се доселио у Кутловац. Са тим Синаном борио се Анђелко Вуковић на живот и смрт 1815. године у трепчанској клисури. Убивши Синана пребегао је у Србију како би избегао крвну освету. О том свом сукобу испевао је песму. Синан, дакле, није био Турчин, како то Вук записује, већ Арбанас, од досељених Арбанаса из скадарске Малесије у до тада српско село Кутловац. Из Вукове белешке сазнајемо да је за време дводневног путовања од Крагујевца до Београда Анђелко Вуку прво приповедао о сукобу са Синаном, а затим претопио то своје приповедање у песму. Ово показује да су наши народни певачи и од прича у невезаном говору стварали песме. Вуковићу то није било тешко да уради, јер је знао велики број стихова и епских песама. Као појаву у усменом песништву Вук означава и то да: „Који човек зна педесет различних пјесама, (ако је за тај посао) њему је ласно нову пјесму спјевати" . Као добар певач, Анђелко је песму стварао за време дводневног путовања с Вуком од Крагујевца до Београда. Ми не знамо да ли је Вук подстакао Вуковића да своју причу о сукобу са Синаном преточи у стихове, јер о томе немамо података. Очигледно је да је Анђелко, стварајући ову песму, користио као узор неку од познатих наших ју-

\footnotetext{
3 Исто.

${ }^{4}$ Исто.

5 Атанасије Урошевић, Косово, Београд, 1965, стр. 92.

6 Исто, стр. XLVII.

7 Вук, Народне српске пјесме, књ. I, Лајпциг 1824, стр. XX.
} 
начких песама о мегданима. Која је то песма била не знамо тачно, јер не знамо које је све јуначке песме с овим мотивом Вуковић знао, осим оних које је Вуку казивао. Видо Латковић је поводом настанка ове песме рекао: „то није ништа друго до варијација на познату песму Марко Краљевић и Муса Кесеиија". Не знамо тачно да ли је Вуковићу баш та песма била позната, али се може тврдити да је знао више песама о сукобима и мегданима, јер је владао песничком техником приликом стварања ове песме. Не знајући које је све песме знао Вуковић, упоредићемо стихове песама које је Вуку казивао са песмом Анђелко Вуковић и Синан Кесеиија. Првих шездесет стихова песме о Анђелку и Синану најбоље сведоче о великој блискости са песмом Мајстор Манојло. Вуковић је позајмио и неке стихове из Женидбе Иве Сеньнина за песму о себи и Синану․․ Има и стихова који су слични песмама других Вукових певача. Део о ватри која се сламом не може угасити, већ се још више распаљује, подсећа на стихове познате Вишњићеве песме Почетак буне против дахија 1804. тета ${ }^{10}$. Песма о Анђелку Вуковићу и Синан Кесеџији ипак највише подсећа на Подруговићеву песму Марко Кральевић и Муса Кесеиија ${ }^{11}$, јер је очигледно грађена по истој старој епској шеми. Вуковић је у изграђену епску шему песме о сукобу јунака уносио специфичности свога доживљаја: у овој песми није заточник већ слободан човек који је дошао на планину да згони овце; не припрема се за мегдан; а епизода о поткивању коња код налбантина (Османа), више подсећа на песму Болани Дојчин ${ }^{12}$. Хладно оружје из Подруговићеве песме замењено је ватреним, а епизода о употреби оружја на мегдану подсећа на слику потезања кубура из песме Женидба Ива Сенанина, коју је Вуковић казивао Вуку. Тај се стих у песми о Иви Сењанину понавља двапут ${ }^{13}$, а у песми о Анђелку и Синану, нешто измењен, четири пута ${ }^{14}$.

Да је Вуковић добро знао песме о мегданима јунака сведочи и композиција песме. У општи, утврђени шаблон песама са овим мотивом Вуковић је врло успешно уткао један конкретан, истинит догађај са многим реалијама и ситуацијама које су се заиста догодиле, или су се, бар пре-

${ }_{8}^{8}$ Видо Латковић, Народна кюижевност, I, Београд, 1967, стр. 40.

9 Вук, Народне српске пјесме, књ. IV, Лајпциг 1823, бр. 45, стихови 17-53.

${ }_{10}$ Вук, Народна србска пјеснарища, у песми О Почетку Србске буне против Дахі_1804. љета, стихови 335-342.

${ }^{11}$ Вук, Народна србска пјеснарииа, песма 6р. 5, стр. 114-124.

12 Вук, Српске народне пјесме, II, Беч, 1841, 6р. 78.

13 Исто, књ. ІІІ, Беч, 1846, бр. 26, стихови 364, 390.

${ }_{14}^{14}$ Вук, Народне српске пјесме, књ. IV, Беч 1833, бр. 45, стихови 268, 276, 285, 289-290. 
ма вероватности, могле догодити. Он је у основи реалистички приказао своју борбу на живот и смрт са Синаном. Имена главних јунака су истинита, а вероватно су стварна и имена осталих јунака у песми. Та се имена могу утврдити и на основу архивске грађе из тога времена. Тачни су и називи појединих места која се помињу у песми: Ораово (Орахово), Кутловац, Засеље, Вучитрн, Митровица, Клисура Трепче, Стари Трг, Манастир у Старом Тргу, Косово. Сви ови називи и данас постоје и означавају иста места као и у Вуковићево време. Уверљиво делује и детаљ о Синану као одметнику од власти и силеџији; разговор Анђелков са Куртом буљубашом; место сукоба је сликано реалистички. Сусрет двојица мегданџија, главних јунака ове песме, приказан је надахнуто. Нарочито су уверљиво опевана психичка стања противника. Сопствени унутрашњи лик Анђелко је изградио зналачки у само три стиха, у којима слика себе као храброг и искусног борца ${ }^{15}$. Синан је окарактерисан као типичан лик силеџије и у томе је потврдио старо правило да су насилници велике кукавице и јадници, што нарочито испољавају када се суоче са јунаком и када се нађу пред смртном опасношћу. Као искусан певач, али и борац и ратник, Вуковић је у песми остварио три савршене слике о узбуђењу мегданџија при сукобу. Прва, о уплашеном јунаковом срцу, делује врло уверљиво, као и друга, о јунаковој срећи: Синан, иако први на потезу, не погађа Анђелка из своје кубуре, јер је превише узбуђен, али зато Анђелко погађа Синана посред груди. Трећа слика је о надолажењу снаге рањеном јунаку: Синан види да му је живот у великој опасности и почиње игру на све или ништа, јер би остало мало наде за спасење једино ако погуби Анђелка. Но, нема среће ни у новом насртају на противника, који му задаје другу рану. Опасност за Вуковића ни тада није прошла. Синан поново напада Анђелка, последњим атомима снаге. У овај део песме Анђелко је, према штуром шаблону песме, увео више силе. Међутим, није се обратио вилама, старим помоћницима јунака, већ хришћанском богу, од кога моли и очекује помоћ као праведан човек и борац. Тако Анђелко скреће радњу песме са реалног тока и мистификује крај сукоба, правећи вештачки преокрет у духу веровања једног побожног хришћанина, сматрајући да су се његовој молби одазвали Бог и свети Никола, избавитељ својих штићеника кад се нађу у невољи. Анђелко наглашава у песми да се бори не за благо, већ за „веру и велику правду”. Вуковић, ипак, није изневерио уметника, јер је преокрет у јуначкој срећи засновао на реалним основама: снага рањеног јунака малаксава убрзо после задобијања тешких рана, крв отиче из тела и снага издаје. Преко ове реалистике слике

${ }^{15}$ Исто, песма бр. 45, стихови 234-236. 
Вуковић је градио завршетак песме: Синан осећа како му се приближава крај и жели да бар мирно умре, па моли свога противника да га више не мрцвари ${ }^{16}$. Вуковић сажаљева немоћног непријатеља, нема срца да му одсече главу и да грди „тела на јунаку”, иако том главом треба да докаже вучитрнском паши да је убио одметника и силеџију. Тим поступком као да мотивише своје одустајање од одласка паши у Вучитрн. Вуковић ослобађа Павла Папуџијћа, кога је Синан водио везанога са собом. Он поручује Павлу да оде вучитрнском паши и каже му да Анђелко Вуковић неће доћи к њему, иако је убио Синана, али га упозорава да га паша више не узнемирава, јер ако то буде чинио - постаће грђи од Синана. И тај вучитрнски паша био је силеџија и неправедни царски чиновник. О Анђелковом напредовању према паши и локалним турским властима сведоче најбоље стихови песме ${ }^{17}$. Анђелко је врло јасно образложио и свој одлазак у Србију, изражавајући мржњу према туђинској власти и ропству.

Стваралац песме Анђелко Вуковић и Синан Кесеиија био је добар песник. Он је знао доста народних песама и био је, како би рекао Вук Караџић, „за тај посао”. Зашто је Вук ипак рекао за Анђелка Вуковића да је „пјевач од средње руке”? Вук је ову оцену изрекао у рачуну од јуначких песама 1833. године. Тада је, вероватно, као своје најбоље певаче издвојио само Тешана Подруговића, Старца Милију, Филипа Вишњића, и можда још којег, а остале је сматрао осредюим. Од слабих певача Вук је ретко објављивао песме. Анђелко Вуковић као стваралац нових песама заостајао је за Вишњићем ван сваке сумње. Међутим, када се Вуковић упореди са осталим Вуковим певачима, ствараоцима нових песама, уочава се да не заостаје за њима. Упоређивањем песме Анђелко Вуковић и Синан Кесеиија са песмама из Вукове IV књиге, установили смо да она није лошија од већине тих записа, већ их својом лепотом надмашује. Зашто онда Вук није у своје бечко, класично издање Српских народних пјесама унео и ову Вуковићеву песму? Вук то није објаснио, вероватно зато што је био тада болестан, о чему и са̂м говори ${ }^{18}$. Можда је Вуковићеву песму оценио као неоригиналну или као песму локалног значаја. Сматрам да естетска вредност није била главни разлог изостављања Вуковићеве песме, јер је Вук био непогрешив у оцењивању лепоте наших народних песама. Вуковић је, без сумње, као стваралац нових песама, спадао у ред бољих Вукових певача, односно песника.

\footnotetext{
16 Исто, стихови 121-128.

17 сто, стихови 121-128.

18 Видо Латковић, Вуков „рачун” од народних пјесама, Ковчежић, II, 1959, стр. 51.
} 
Анђелко Вуковић није био само добар стваралац епских песама о савременим догађајима, већ и одличан народни певач, преносилац епских народних песама. О томе сведоче епске песме које је Вук записао од њега: једна о хајдуцима Мајстор Манојло ${ }^{19}$, две о ускоцима Женидба Ива Сенанина ${ }^{20}$ и Млади Марјан и Арнаут Осман ${ }^{21}$ и једна новија, о одбрани манастира Дечана од пљачкаша из Скадра, Jаут-бег и Перо Мркоюи ${ }^{22}$. Овим песмама треба додати и епску песму приповедног карактера 3мија младожена ${ }^{23}$.

Варијанте с мотивом песме Мајстор Манојло записане су и у другим крајевима ${ }^{24}$, али је Вуковићева варијанта без премца. У њој је осуђена једна неправда нанета обичном, сиромашном човеку. Да би спасао свој голи живот, мајстор Манојло бежи у гору и постаје хајдук. По основној идеји, да је мали, сиромашни човек незаштићен и да му се чине неправде врло је блиска песми Старина Новак и кнез Богосав ${ }^{25}$. Социјални елементи, наглашени и у једној и у другој песми врло су значајни. Мотив о неверном кумству и размени деце кумчади је стар, а везивање овог мотива за Манојлово име ни мало ближе не одређује ни време ни личност, јер је све у овој песми неисторијско. Одметање у хајдуке, што је карактеристично за наша „средња времена”, навело је Вука да песму уврсти у хајдучки циклус. Песма Мајстор Манојло је права антологијска песма и спада у ред наших најлепших приповедних епских песама, и право је чудо што није то место и заузела у нашим антологијама народне епике.

Друге две јуначке песме „средњих времена” припадају ускочком циклусу и у њима је опеван омиљен ускочки вођа и јунак Иво Сењанин. У песми Женидба Ива Сеньнина главни јунак је Комнен барјактар. Песма почиње описом Сењанина пред којима се Иво заклиње да ће се оженити лепом Хајком, сестром Фрце Ибрахима. То ствара предиспозицију за развој радње, за разгранавање сижеа. Али тај план не остварује Иво, већ његов брат Комнен барјактар. Иво обећава велику награду ономе јунаку ко би му „задобио Хајку”. Тада се јавља Комнен барјактар, скупља чету ускока, проверава храброст својих другова. Необично је то испитивање храбрости. Комненова чета се осипа и после дугог конака остаје му само

19 Вук, Српске народне пјесме, Беч, 1846, књ. III, бр. песме 45.

20 Исто, песма бр. 26.

21 Исто, песма бр. 27.

22 Исто, IV песма бр. 16.

${ }^{23}$ Исто, II песма бр. 12.

${ }_{24}$ Исто, књ. IV, бр 3; Новица Шаулић, Српске народне пјесме, књ. I, Београд, 1929, бр. 90, 94.

${ }^{25}$ Вук, Српске народне пјесме, књ. III, песма бр. 1. 
пет-шест другова. Са њима је и Иво Сењанин, преплашен толико да „И он гледа, да ка Сењу бега”. Зато Комнен одлучује да са̂м изврши овај задатак. Својим јунаштвом, лукавством и вештином побеђује турске јунаке и на крају ослобађа из турског ропства сестру Анђелију и тридесет сењских девојака. Да би песму учинио интересантнијом и још више прославио свог омиљеног јунака Комнена барјактара, Вуковић је додао слику града Сења. Она представља велики обрт у песми: жалост за Комненом, његовом сестром Анђелијом и тридесет сењских девојака претвара се у радост и весеље. И у песми Опет женидба Сенанина Ива, ${ }^{26}$ коју је Вук записао од непознатог певача, главни јунак је Ивов сестрић Тадија, који уплашеном ујаку говори прекорне речи: „Не плаши ми по планини друга, / а ти бјежи куда теби драго”. Своје младићко уплашено срце са̂м теши и кори: „Што си ми се срце уплашило? / Једном си се од мајке родило, / а други ћеш, срце, умријети”. И Вуковићева песма Женидба Ива Сеюанина такође спада у ред наших најлепших јуначких народних песама.

У песми Млади Марјан и Арнаут Осман опеван је Иво Сењанин као неспретан јунак. Он се нашао, са целом дружином, због своје лаковерности у смртној опасности. Главни јунак ове песме је млади ускок Марјан, кавгаџија, јунак који својом срчаношћу, попут Ивовог сестрића Тадије у песми Женидба Ива Сенанина, спасава Ива и његову дружину. Иву Сењанину због неспретности и наивности није упућен само прекор, већ и оштра претња. Разјарени Марјан, пошто је погубио Панџу, „до Иве је сабљу дотерао”. И ко зна како би се све завршило „да га није задржало друсто”, јер, како каже певач: „и њега би онде погубио, / зашто држи веру у Турчина". Вук је објавио и једну варијанту ове песме из Црне Горе од непознатог певача ${ }^{27}$. Вуковићева песма је врло слична једном кругу песама у којима је опеван мотив о братимљењу и пријатељству ${ }^{28}$.

Када се проуче песме Анђелка Вуковића о Иву Сењанину, стиче се утисак да певач није био склон овом нашем истакнутом и најопеванијем ускочком јунаку. Да ли је Вуковић такве песме слушао и научио, или по-

26 Исто, песма бр. 27.

27 Исто, песма бр. 30.

28 Видети: Герхард Геземан, Ерлангенски рукопис старих српскохрватских народних песама, Сремски Карловци, 1925, песма бр. 168; Вук, Српске народне nјесме, III, Беч, 1846, бр. 50; књ. IV, Београд, 1899, песма бр. 80, 81; „Даница”, IV, 1863, стр. 741, бр. 10; Владимир Красић, Српске народне песме, I, Панчево, 1880, бр. 17; „Јавор”, 1888, стр. 55; Манојло Кордунаш, Српске народне песме, II, Нови Сад, 1892, бр. 24; „Српски етнографски зборник”, XVI, стр. 323; „Нова Зета”, II, бр. 56. 
стоје други разлози, тешко је закључити, јер немамо о томе поузданих података.

Вуковићева песма о змији младожењи штампана је у два облика. Први пут Вук је објавио у Предговору IV књиге лајпцишог издања у Бечу 1833. године, а затим као посебну варијанту у II књизи бечког издања, 1845. године, под бројем дванаест. Вероватно се ради и о два записа песме. Вук је текст забележио најпре у Крагујевцу 1821. године и тада објаснио зашто песма није цела у стиху, већ се смењују стих и прозно казивање. Као разлог таквог поступка навео је самог Вуковића, који је „на ђекојим мјестима готово приповиједао (овако као и ја)”29. Највећи део сижеа је препричан. Не зна се када је Вук други пут записао песму од Вуковића, али је тада допунио - стихови су заменили препричавање - и објавио у бечком издању под насловом Змија младожењ $a^{30}$. Песма о змији младожењи заслужује посебан осврт и због тога што је двапут објављена у различном руху. Првим записом песме Вук није био задовољан због њене фрагментарности па је зато и оценио њеног казивача као осредњег. Ако је то био једини разлог Вукове оцене вредности свог певача са Косова, она је била преурањена. И таква песма, саопштена делом у прози, а делом у само 168 стихова, привукла је пажњу Јакова Грима. Интересовање овог немачког научника за песму о змији младожењи подстакло је и Вука. Видо Латковић је претпоставио: „Прозне делове, сва је прилика, сам је Вук преточио у десетерце, подешавајући језик према језику Анђелка Вуковића"з1. Љубомир Стојановић је сматрао да је Вук „доцније целу чуо и издао" ${ }^{2}$. Стојановићевом мишљењу може се додати да је и други пут Вук песму записао од Анђелка Вуковића, свог певача са Косова. То показује поређење нових стихова са стиховима из других раније записаних Вуковићевих песама ${ }^{33}$.

Шест песама, које је Вук записао од Анђелка Вуковића, јединог свог певача са Косова и Метохије, садрже 1318 стихова. Оволики број записа епских песама од једног певача са Косова, са којим је Вук боравио врло мало времена, уверљиво говори да је народна епика на Косову почетком XIX века била врло жива, како приповедна, тако и јуначка. Многи стари

29 Вук, Народне српске пјесме, књ. I, стр. XLVII.

30 Вук, Српске народне пјесме, књ. II, песма бр. 12.

31 Видо Латковић, нав. дело, стр. 51.

32 Љубомир Стојановић, Живот и рад Вука Стеф. Каращића, Београд, 1925, стр. 238.

33 Владимир Бован, Вуков певач Анђелко Вуковић, „Зборник реферата и саопштења са научних састанака слависта у Вукове дане”, III, Београд, 1974, стр. $480-482$. 
мотиви били су добро сачувани, али је живо негована и народна епика „средњих времена”, као и новија јуначка песма. Вук од Анђелка није записао преткосовске песме, песме о косовском боју и покосовске, можда због тога што их певач није најбоље знао или их је знао онако како су се тада певале на самом Косову. Могуће је да се нису Вуку допале, јер је већ записао о косовској бици лепше, развијеније, потпуније песме. Да су песме „старих времена” живеле на Косову и пре и после Вуковића, сведоче каснији записи, почев од осамдесетих година XIX века па до ослобођења Косова и Метохије од Турака. Можда је, ипак, заједнички кратак боравак главни разлог што Вук од Анђелка није записао и песме са „старијом” тематиком. Вук од Анђелка није записао ниједну лирску народну песму, а сигурно их је Вуковић знао. Анђелко вероватно није поклањао довољно пажње лирским народним песмама и није му падало на памет да их казује Вуку, јер није стигао да му каже ни све епске песме које је знао. Из Вуковог записа о Анђелку Вуковићу стиче се утисак као да Вук није био посебно заинтересован за његове песме. Са̂м Анђелко морао је молити неког писменог трговца да му једне вечери на конаку, у путу од Крагујевца до Београда, запише песму о мегдану са Синаном Кесеџијом. Вероватно је Вук касније зажалио за овим певачем, што потврђује и чињеница да се вратио песми о змији младожењи.

Вукова збирка епских народних песама са Косова, која је настала из казивања Анђелка Вуковића, јесте прва поуздана збирка српских народних песама из ових крајева. Она пружа слику стања српске народне епике на Косову почетком XIX века и даје богат песнички прилог ових крајева српској народној поезији, представљеној у класичној збирци Вука Караџића Српске народне пјесме. Вук је у својим записима о Анђелку Вуковићу први рекао нешто и о певачима тих песама. Иако је Вук био шкрт у речима када је писао о свом певачу са Косова, ипак га је рељефно представио читаоцима. У записима о Вуковићу рекао је које је песме од њега записао, где и када. О Вуковићу је писао као о човеку кога је познавао и као ратника врло ценио. Али, ценио га је и као певача, без обзира што га је мало престрого у почетку сврстао међу певаче од средње руке. По Вуку је и као човек добар, поштен и побожан, а да је велики јунак, показују детаљи из његовог ратничког живота. У борби против Турака учествовао је у другом српском устанку, као пребег са Косова, као родољуб и борац за правду и слободу свога народа. Да је Вук променио своје првобитно мишљење о Вуковићу као певачу, сведочи „рачун од јуначких песама”. Пре Вуковића су у том „рачуну” само Подруговић, Вишњић, Милија, Рашко, Стојан хајдук, Ђуро Милутиновић, Гаја Балаћ, слепа Живана. Иза Анђелка су такође значајни Вукови певачи: Трговац из Босне, Груја 
Механџић, Филип Бошковић и Милован Мушикин, оба из Црне Горе, сељак из Рудничке нахије, затим Рово, слепа Степанија, Павле Ирић и други. Вук у „рачуну” није поново вредновао певача Анђелка Вуковића, али девето место које му је дао међу својим певачима показује колико је Вук високо ценио Анђелка Вуковића као свог певача јуначких народних песама. Анђелко је својим песмама показао да је био одличан зналац великог броја јуначких народних песама које су се певале у његовом завичају. Као преносилац старих и стваралац нових песама, Вуковић се може надметати са најбољим Вуковим певачима и по начину грађења композиције и по умешности вођења радње.

Значај Вука Стефановића Караџића као сакупљача српских народних песама са Косова није само у томе што је он први записивач народних песама са овог подручја, већ и што су ти записи песама сасвим аутентични, поуздани. Они чине обиман фонд од шест песама са преко 1300 чистих епских десетераца, и могу представљати одличан пресек стања епског народног певања на самом Косову почетком XIX века. Посебно треба нагласити да су песме које је Вук записао од Анђелка Вуковића веома лепе и по квалитетима улазе у најстрожије антологије епских народних песама са Косова и Метохије од почетка њиховог записивања па до данас.

* Рад је претходно објављен у зборнику Научни састанак слависта у Вукове дане, 17/3, 67-76. 